Published by LPMP Imperium

Journal homepage: https:/ / ejournal.imperiuminstitute.org/ index.php/AKURASI

\title{
PERPUTARAN UANG DI INDONESIA: PERAN UANG ELEKTRONIK, VOLUME TRANSAKSI ELEKTRONIK DANJUMLAH MESIN EDC
}

\section{AKURASI}

\section{9}

\author{
Muhammad Fadlillah Fauzukhaq ${ }^{1 *}$ Luthfan Darma \\ Prasetia², Akhmad A kbar ${ }^{3}$ \\ Paper type \\ Research paper
}

1-2Fakultas Ekonomi dan Bisnis UIN Syarif Hidayatullah Jakarta

3Fakultas Ekonomi Universitas Pamulang

\begin{abstract}
The purpose of this study is to analyze the effect of theuse of electronic money which includes the amount of electronic money in circulation, the volume of electronicmoney transactions and the number of electronic money EDC machines on the velocity of moneyin Indonesia. The data used in the study are secondary data from the Central Statistics Agency (BPS) and the Central Bank (BI) and analyzed by linear regression. The results showed that the amount of electronic money incirculation and the number of Electronic Data Capture (EDC) Machines had a significant effect on the velocity of money in Indonesia, while the volume of electronic money transaction sdid not have a significant effect on the velocity of money in Indonesia.
\end{abstract}

\begin{abstract}
Abstrak
Penelitian ini dilakukan dengan tujuan menganalisa pengaruh penggunaan uang elektronik, yang terdiri dari variabel jumlah uang elektronik yang beredar, volume transaksi uang elektronik dan jumlah mesin EDC terhadap perputaran uang di Indonesia. Data yang digunakan dalam penelitian adalah data sekunder yang berasa dari Badan Pusat Statistik (BPS) dan Bank Sentral (BI) dan dianalisis dengan regresi linier.Hasil Penelitian menunjukkan bahwa variabel jumlah uang elektronik yang beredar, dan jumlah mesin EDC berpengaruh secara signifikan terhadap perputaran uang di Indonesia, sedangkan volume transaksi uang elektronik tidak berpengaruh signifikan terhadap perputaran uang di Indonesia.
\end{abstract}

Email korespondensi: fadlillah.fauzukhaq@injkt.ac.id

Pedoman Sitasi: Fauzukhaq, M.F., Prasetia, L.D., \& Akbar, A. (2019). Perputaran Uang Elektronik di Indonesia. AKURASI: Jurnal Riset Akuntansi dan Keuangan, 1(2),79-88

DOI: https:/ / doi.org/ 10.36407/ akurasi.v1i2.92
Received: 17 Sep 2019

Accepted: 18 Dec 2019

Online: 20 Dec 2019

Keywords: electronic money, velocity of money, multiple regression analysis

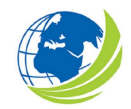

Akurasi: Jurnal Riset Akuntansi dan Keuangan, Vol 1, No.2, Desember 2019, pp. 79-88 eISSN: 2685-2888 


\section{PENDAHULUAN}

Gaya hidup masyarakat di zaman modern sangat dipengaruhi oleh perkembangan teknologi, salah satunya dalam hal pembayaran. Sistem pembayaran yang awalnya hanya menggunakan uang tunai sebagai alat pembayaran, sekarang berkembang menjadi pembayaran elektronik. Perkembangan sistem pembayaran tersebut mengikuti perkembangan teknologi, hal tersebut menjadi salah satu peluang bagi perbankan untuk menerapkan sistem pembayaran elektronik.

Bank Indonesia merupakan lembaga negara yang memiliki otoritas mengatur sistem pembayaran di Indonesia telah membuat desain besar dalam meningkatkan jumlah penggunaan pembayaran non tunai Toward a Less CashSociety(LCS). Sistem pembayaran uang tunai mulai tergantikan oleh sistem pembayaran elektronik. Dengan tujuan negara dapat menghemat biaya pencetakan uang tunai dan penghematan biaya transaksi, maka digerakan perubahan dari transaksi tunai menuju transaksi elektronik.

Penelitian yang membahas mengenai permintaanuang elektronik (e-money) telah menarik banyak perhatian dalam limatahun terakhir. Cohen (2010) menyebutkan bahwa ada kecenderungan kesulitan yang dialami oleh bank sentral di berbagai negara dalam mengendalikan agregat moneter karena percepatan persaingan lintas batas antar mata uang, dandampak yang ditimbulkanolehuang elektronik akan hanya menambah intensitas kompetisi tersebut. Studi lebih baru yang dilakukanoleh Dou (2018) menyebutkanbahwapermintaan uang elektronik di Cina terutama ditentukan oleh pendapatan, tingkat bunga dan tingkat inflasi yang diharapkan. Namun, faktor-faktor lain, seperti inovasi keuangan, utang pemerintah, mobilitas modal, dan penggantian mata uang, memainkan peran yang relatif kecil, terutama karena sistem keuangan dan moneter China sedang dalam reformasi. Hasil regresi data sampel dari periode yang berbeda menunjukkan bahwa permintaan uang di Cina tidak stabil, menunjukkan bahwa ekonomi makro China memiliki risiko tertentupadapermintaan e-money. Dalam konteks yang berbeda, studi yang dilakukan oleh Lu dan Su (2017) menguji hubungan antara permintaan e-money dengan likuiditas moneter di China. Hasil penelitiannya menunjukkan bahwa uang elektronik memiliki efek substitusi yang berbeda pada mata uang dengan likuiditas yang kuat, tetapi substitusi ini bukan bentuk substitusi yang sederhana.

Studi yang dilakukan di Indonesia mengenai permintaan e-money masih sangat terbatas dan lebih banyak fokus pada intensi penggunaan e-money (misalnya Ramadani, 2016; Junaidi, 2015). Studi Ramadani (2016) menguji penggunaan kartu debit dan uang elektronik memiliki pengaruh positif dan signifikan terhadap pengeluaran konsumsi mahasiswa, sedangkan Junaidi (2015) menguji model unified theory of acceptance and use of technology (UTAUT) untuk memprediksi perilaku penggunaan uang elektronik. Hasilnya menunjukkan bahwa tidak hanya dalam hal penerimaan teknologi, tetapi faktor-faktor lain yang dianggap berpengaruh pada konsumen seperti budaya dan persepsi keamanan di negara asal. Masih terbatasnya studi mengenai permintaan e-money di Indonesia menjadikan isu ini masih memiliki ruang yang luas untuk dieksplorasi.

Berdasarkan keterbatasan tersebut, penelitian ini berupaya menutupi kesenjangan yang ada dengan melakukan eksplorasi untuk mengetahui perkembangan alat pembayaran menggunakan Uang Elektronik (E-Money) di Indonesia. Pada saat yang sama, artikel ini ditujukan untuk mengetahui pengaruh jumlah uang elektronik yang beredar, volume transaksi, jumlah mesin EDC terhadap perputaran uang di Indonesia. Selain itu, penelitian ini memberikan manfaat bagi Pemerintah, Perbankan dan Institusi perekonomian lainnya dalam bentuk hasil penelitian tentang pengaruh jumlah uang elektronik yang beredar, volume transaksi, jumlah mesin EDC terhadap perputaran uang di Indonesia, dan langkah langkah yang perlu dilakukan dalam percepatan pertumbuhan uang elektronik di Indonesia.

\section{KAJIAN PUSTAKA}

Konsep pembayaran elektronik dilakukan dengan mengkonversi uang dengan wujud fisik (uang tunai) sebagai alat pembayaran dengan cara menyetorkan atau transfer antar bank. Perkembangan teknologi telah memberikan pengaruh kepada sistem pembayaran elektronik disertai munculnya berbagai inovasi- 
inovasi baru dalam pembayaran elektronis, seperti pembayaran melalui: phonebanking, internet banking, pembayaran dengan kartu kredit dan kartu debit/ ATM.

Beberapa instrumen pembayaran elektronik yang sedang berkembang saat ini sepeti mobilebanking dan pembayaran digital, Penelitian ini membahas isu utama dalam sistem pembayaran elektronik meliputi: inovasi sistem pembayaran elektronik, di mana nilai uang pada uang elektronik adalah jumlah uang yang disetorkan terlebih dahulu oleh pihak pemegang kartu uang elektronik kepada pihak penerbit uang elektronik. Jumlah uang yang disetorkan ke penerbit uang elektronik selanjutnya disimpan secara elektronik dalam pada server atau chip, nilai uang tersebut dapat dipindahkan sesuai dengan kepentingan transaksi pembayaran. Jumlah uang yang tersimpan pada uang elektronik bukan simpanan yang dimaksud pada Undang-Undang Nomor 10 tahun 1998 tentang Perbankan dan Undang-Undang Nomor 21 Tahun 2008 tentang Perbankan Syariah, sehingga tidak memperoleh bunga atas simpanannya dan juga tidak dijamin oleh Lembaga Penjamin Simpanan (LPS).

Uang elektronik dapat dibedakan dengan alat pembayaran elektronik berbasis kartu lainnya seperti kartu debit dan kartu kredit. Kartu debit dan kartu kredit adalah kartu dengan karakteristik accessproducts, dimana salah satu karakteristiknya adalah kartu debit atau kartu kredit melakukan transaksi secara on-line dan tersambung pada komputer penerbit kartu. Sedangkan uang elektronik (e-money) adalah alat pembayaran non tunai yangmeiliki karakteristik prepaidProducts,dimana transaksi yang dilakukan tidak on-linedan tersambung ke penerbit kartu, tetapi dilakukan secara off-line ke terminal merchant.

Perputaran uang (velocity of money) adalah jumlah rata-rata transaksi perputaran uang dalam setahun, dengan menggunakan satuan unit mata uang untuk membeli total barang dan jasa yang di produksi dalam perekonomian (Mishkin, 2008:186). Teori tersebut membahas hubungan jumlah uang beredar dengan total produksi barang dan jasa (PDB). Percepatan penggunaan uang elektronik tergantung pada institusi yang berperan dalam perekonomian untuk mempengaruhi konsumen perorangan dalam tata cara bertransaksi. (Irving Fisher dalam Mishkin 2008:187)

Beberapa teori tentang Perputaran uang dikembangkan oleh beberapa ahli ekonomi antara lain: Irving Fisher, dengan menggunakan pendekatan teori kuantitas klasik. Fisher melakukan pembahasan hubungan jumlah total uang (M) dengan total pengeluaran dari barang dan jasa yang diproduksi dalam perekonomian ( $\mathrm{P}$ x Y), di mana $\mathrm{P}$ adalah tingkat harga dan Y adalah output agregat. Konsep ini disebut dengan perputaran uang (velocity of money), yaitu jumlah rata-rata pertahun dari satu unit mata uang untuk membeli total barang dan jasa yang diproduksi yang dinyatakan dalam V (velocity). V merupakan total pengeluaran ( $\mathrm{P}$ x $\mathrm{Y}$ ) yang dibagi dengan jumlah uang (M).

$$
\boldsymbol{V}=\frac{\boldsymbol{P} \times \boldsymbol{Y}}{\boldsymbol{M}}
$$

Dengan mengalikan kedua sisi persamaan tersebut dengan $\mathrm{M}$, maka dapat disederhanakan dengan "persamaan pertukaran" (equation of exchange) sebagai berikut:

$\boldsymbol{M} \times \boldsymbol{V}=\boldsymbol{P} \times \boldsymbol{Y}$

Dimana : M - Jumlah total uang, V - Perputaran uang (velocity of money), Y - Output Agregat, dan P - Tingkat Harga.

Persamaan tersebut menyatakan bahwa jumlah uang dikalikan dengan perputaran uang dalam satu tahun yang sama dengan pendapatan nominal. Irving Fisher berpendapat bahwa percepatan penggunaan uang elektronik ditentukan oleh institusi perekonomian memberikan pengaruh terhadap cara individu untuk melakukan transaksi. Jika uang elektronik (e-money) telah digunakan oleh masyarakat dalam bertransaksi maka, penggunaan uang tunai berkurang, sehingga semakin sedikit uang tunai yang dibutuhkan untuk bertransaksiuntuk sebuah pendapatan, dan percepatan penggunaan uang elektronik akan naik. Sebaliknya, 
kalau dalam melakukan pembelian lebih mudah dengan uang tunai, maka lebih banyak uang tunai digunakan untuk transaksi yang dihasilkan oleh jumlah pendapatan nominal yang sama, dan percepatan akan menurun. Fisher berpendapat bahwa bentuk institusi dan teknologi dari suatu perekonomian hanya akan memengaruhi percepatan secara lambat sepanjang waktu, sehingga percepatan biasanya konstan dalam jangka pendek (Mishkin, 2009; 187).

Selain teori yang dikemukakan Irving Fisher, J.M. Keynes memiliki pandangan yang berbeda terhadap pandangan klasik yang menyatakan bahwa percepatan adalah konstan. Kemudian Keynes mengembangkan teori tersebut menjadi teori preferensi likuiditas (liquiditypreferencetheory), yang bertanya mengapa individu memegang uang.

Menurut teori permintaan uang Keynes, ada 3 motif masyarakat membutuhkan uang yaitu: i). Motif transaksi - komponen permintaan uang akan ditentukan oleh besaran tingkat transaksi seseorang. Oleh karena itu, dia mengambil komponen transaksi permintaan akan uang terhadap pendapatan. Apabila terjadi kenaikan pendapatan maka permintaan uang akan naikjuga.

$M_{T}^{d}=f(Y)$

Motif berjaga-jaga - Keynes menyadari bahwa selain untuk bertransaksi, seseorang menyimpan uang sebagai antisipasi atas kebutuhan yang mendadak. Sehingga dia merumuskan permintaan akan uang berjaga-jaga proporsional terhadap pendapatan. Jika pendapatan naik, maka permintaan uang untuk berjaga-jaga juga naik.

$M_{P}^{d}=f(Y)$

Motif spekulasi - Diasumsikan permintaan uang terpengaruh oleh tingkat suku bunga. Semakin tinggi suku bunga, semakin kecil keinginan masyarakat memegang uang kas untuk spekulasi, yang berarti masyarakat akan mengurangi memegang uang dan akan menabungkan uang tersebut.

$M_{S}^{d}=f(R)$

Sehingga dapat ditulis menjadi :

$M_{1}=M_{T}^{d}+M_{P}^{d}$

$M_{2}=M_{S}^{d}$

$M^{d}=M_{1}+M_{2}$

Permintaan uang secara keseluruhan dapat ditulis dengan rumus :

$M^{d}=f(Y)+f(R)$

Keterangan $: \boldsymbol{M}_{\boldsymbol{T}}^{\boldsymbol{d}}=$ permintaan uang untuk transaksi, $\boldsymbol{M}_{\boldsymbol{P}}^{\boldsymbol{d}}=$ permintaan uang untuk jaga-jaga, $\boldsymbol{M}_{\boldsymbol{S}}^{\boldsymbol{d}}=$ permintaan uang untuk spekulasi, $\boldsymbol{M}_{\mathbf{1}}=$ Uang beredar dalam arti sempit, dan $\boldsymbol{M}_{\mathbf{2}}=$ Uang beredar dalam arti luas.

Saat ini, indikator resmi yang digunakan untuk mengukur perkembangan alat pembayaran elektronik di Indonesia masih sangat terbatas. tetapi secara umum indikator pengukuran yang digunakan untuk mengukur perkembangan pembayaran elektronik terdiri tiga indikator yaitu indikator perkembangan 
volume transaksi alat pembayaran non tunai, rasio antara konsumsi swasta terhadap uang tunai di masyarakat dan rasio uang tunai terhadap M1 (Hidayat, 2006).

Berdasarkan uraian di atas dapat disimpulkan bahwa perkembangan teknologi memberikan pengaruh terhadap kehidupan masyarakat terutama dalam hal melakukan transaksi dalam upaya untuk memenuhi kebutuhan.

\section{METODE PENELITIAN}

Metode yang digunakan pada Penelitian ini terdiri dari metode pengumpulan data dan metode analisas data, metode pengumpulan data menggunakan data runtut waktu atau timeseries, selanjutnya analisa data dengan menggunakan alat analisis regresi. Data timeseries merupakan data yang terdiri dari satu objek tetapi meliputi beberapa periode waktu (Winarno, 2009 : 2.2).Adapun data yang digunakan dalam penelitian ini terdiri dari perputaran uang yang dihitung dengan membagi PDB riil (Y) dengan jumlah uang beredar (M), jumlah uang elektronik beredar, volume transaksi uang elektronik, dan jumlah mesin EDC uang elektronik. Data tersebut berasal dari publikasi Bank Indonesia dan BPS.

Model persamaan yang digunakan dalam menganalisis data ini adalah: $P U_{i t}=\beta_{0}+\beta_{1} J U E B_{i t}+\beta_{2} V T U E_{i t}+\beta_{3} J M U E_{i t}+\varepsilon_{i t}$

Dimana : PU ${ }_{i t} \quad$ - Perputaran uang, $\beta_{0}$ - Konstanta/ Intercept, $\beta_{0} \ldots \beta_{\mathrm{n}}$ - Koefisien Regresi, JUEB ${ }_{i t}-$ Jumlah uang elektronik yang beredar, $\mathrm{VTUE}_{\mathrm{it}}$ - Volume transaksi uang elektronik, JMUE $\mathrm{E}_{\mathrm{it}}$ - Jumlah mesin uang elektronik, dan $\varepsilon_{\mathrm{it}}$ - Standard Error.

\section{HASIL DAN PEMBAHASAN}

Uji Asumsi Klasik

Uji Normalitas digunakan untuk menguji variabel dependen dan independen berdistribusi normal atau tidak, pada penelitian ini uji formalitas yang digunakan adalah Jarque-BeraTest, jika nilai Jarque-Bera $<2$ maka data berdistribusi normal atau nilai Probability> tingkat signifikansi yang digunakan. (Winarno, 2011: 5.39)

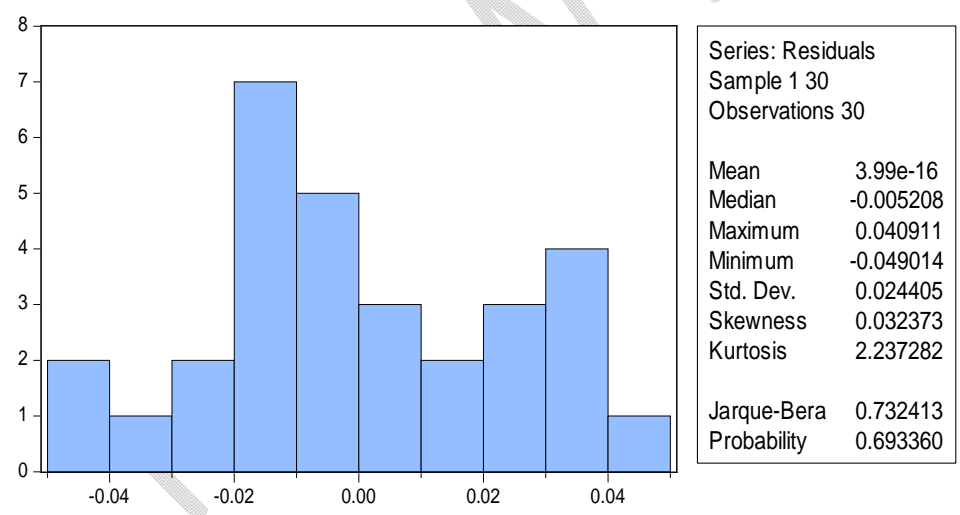

\section{Gambar 1. Hasil Uji Normalitas}

Pada gambar 1 di atas, dapat diketahui bahwa nilai Jarque-Bera sebesar 0,732413< 2 atau probabilityJarque-Bera sebesar 0,693360 >0,05 maka dapat dinyatakan bahwa hasilnya adalah menerima $\mathrm{H}_{0}$ atau data berdistribusi normal.Selanjutnya uji multikolinearitas digunakan untuk menguji apakah suatumodel regresi terdapat korelasi antar variabel bebas (independen). Pengujian multikolinearitas diperoleh dari besaran VIF (VarianceInflationFactor) dan tolerance. Tolerance mengukur variabel independen yang terpilih tidak dijelaskan oleh variabel independen lainnya. Jadi nilai tolerance yang 
rendah sama dengan nilai VIF yang tinggi (karena VIF $=1$ / tolerance). Nilai cut off yang digunakan untuk menunjukkan adanya multikolinearitas adalah adalah nilai tolerance $\geq 0,01$ atau sama dengan nilai VIF $\leq 10$. (Ghozali, 2012:105) Berikut tabel hasil uji multikolinearitas.

Tabel 1. Hasil Uji Multikolinearitas

\begin{tabular}{|l|l|l|l|}
\hline Variable & CoefficientVar & Uncentered VIF & Centered VIF \\
\hline C & 0.034528 & 1559.160 & NA \\
\hline LJUEB & 0.000353 & 4559.790 & 9.224163 \\
\hline LVTUE & 0.000358 & 4357.349 & 21.97578 \\
\hline MESIN_EDC & $1.48 \mathrm{E}-14$ & 26.98521 & 8.897949 \\
\hline
\end{tabular}

Sumber: Hasil Pengolahan Data dengan Eviews 9

Tabel 1 menjelaskan Nilai VIF pada variabel Jumlah Uang Elektronik Beredar, Volume Transaksi Uang Elektronik dan Jumlah Mesin EDC Uang Elektronik berturut-turut adalah 9.224163, 21.97578, dan 8.897949. Berdasarkan hasil tersebut terdapat variabel yang memiliki nilai VIF > 10 maka model regresi terindikasi oleh multikolinearitas atau terdapat variabel independen yang memiliki hubungan liniear dengan variabel independen lainnya.

Selanjutnya dilakukan uji autokorelasiuntuk melihat hubungan antara residual satu observasi dengan residual observasi lainnya. Pengujian autokorelasi dilakukan dengan uji Breusch-Godfrey Serial CorrelationLagrangeMultiplier Test (uji LM). Uji ini sangat berguna untuk mengidentifikasi masalah autokorelasi tidak hanya pada derajat pertama tetapi bisa juga digunakan pada tingkat derajat. Dikatakan terjadi autokorelasi jika nilai X2 (Obs*R-Squared) hitung > X2 tabel atau nilai Probability< derajat kepercayaan yang ditentukan (Ningsih dalam Irfan Tripurwanta, 2017:66).

\section{Tabel 2. Hasil Uji Autokorelasi}

Breusch-Godfrey Serial Correlation LMTest:

\begin{tabular}{|l|l|l|l|}
\hline F-statistic & 1.355836 & Prob. F(4,22) & 0.2813 \\
\hline Obs*R-squared & 5.932912 & Prob. Chi-Square(4) & 0.2042 \\
\hline
\end{tabular}

Sumber: Hasil Pengolahan Data dengan Eviews 9

Tabel 2 menunjukkan bahwa nilai ProbabilityChi-Square sebesar 0,2042>0,05 dimana dapat disimpulkan bahwa hasilnya adalah menerima $\mathrm{H}_{0}$ atau data tidak mengalami masalah autokorelasi.

Uji Koefisien Determinansi

Uji koefisien determinasi digunakan untuk mengukur kemampuan variabel independen, yaitu Jumlah Uang Elektronik Beredar, Volume Transaksi Uang Elektronik, dan Jumlah Mesin EDC Uang Elektronik di Indonesia menjelaskan variabel dependen yaitu Perputaran Uang di Indonesia menggunakan. Hasil uji koefisien determinasi sebagi berikut: Nilai koefisien determinasi sebesar 0.974409 atau $97.44 \%$. Dengan ini terlihat bahwa 97.44\% Perputaran Uang dapat dijelaskan oleh Jumlah Uang Elektronik Beredar, Volume Transaksi Uang Elektronik, dan Jumlah Mesin EDC Uang Elektronik. Sedangkan sisanya $(100 \%-97.44 \%=$ 2.56\%) Perputaran Uang dijelaskan oleh variabel lain yang tidak diteliti dalam penelitian ini.

Uji Hipotesis

Pengujian hipotesis dalam penelitian ini dilakukan dengan menggunakan regresi berganda (multipleregressionanalysis), yaitu dilakukan melalui uji statistik t dan uji statistik F. 
AKURASI, 1(2), 79 - 88

Fauzukhaq, M.F., Prasetia, L.D., \& Akbar, A. Perputaran Uang di Indonesia....

Uji statistik t digunakan untuk mengetahui ada atau tidaknya pengaruh masing-masing variabel independen secara individual terhadap variabel dependen yang diuji pada tingkat signifikansi 0.05 . Jika nilai probabilityt lebih kecil dari 0.05 maka $\mathrm{H}_{1}$ diterima dan menolak $\mathrm{H}_{0}$, sedangkan jika nilai probability $\mathrm{t}$ lebih besar dari 0.05 maka $\mathrm{H}_{0}$ diterima dan menolak $\mathrm{H}_{1}$. Berikut tabel yang menunjukkan hasil uji statistik t.

Tabel 3.Hasil Uji Statistik t (Parsial)

\begin{tabular}{crrrr}
\hline \hline Variable & Coefficient & Std. Error & t-Statistic & Prob. \\
\hline \hline C & 3.413196 & 0.185816 & 18.36864 & 0.0000 \\
LJUEB & -0.121435 & 0.018793 & -6.461835 & 0.0000 \\
LVTUE & -0.025286 & 0.018925 & -1.336113 & 0.1931 \\
MESIN_EDC & $-2.67 \mathrm{E}-07$ & $1.22 \mathrm{E}-07$ & -2.196188 & 0.0372 \\
\hline \hline
\end{tabular}

Sumber: Hasil Pengolahan Data dengan Eviews 9

Pada tabel3diatas, menunjukkan hasil uji statistik t antara variabel independen dengan variabel dependen sebagai berikut:

Hipotesis 1: Pengaruh Jumlah Uang Elektronik Beredar Terhadap Perputaran Uang.Variabel LJUEB (Jumlah Uang Elektronik Beredar) memiliki nilai probabilitas statistik t sebesar $0.0000<0.05$ yang berarti menerima $\mathrm{H}_{0}$ sehingga dapat dikatakan bahwa Jumlah Uang Elektronik Beredar mempunyai pengaruh signifikan terhadap Perputaran Uang di Indonesia tahun 2010-2016.Hipotesis 2: Pengaruh Volume Transaksi Uang Elektronik Terhadap Perputaran Uang. Variabel LVTUE (Volume Transaksi Uang Elektronik) memiliki nilai probabilitas statistik t sebesar $0.1931<0.05$ yang berarti menolak $\mathrm{H}_{0}$ sehingga dapat dikatakan bahwa Volume Transaksi Uang Elektronik tidak mempunyai pengaruh signifikan terhadap Perputaran Uang di Indonesia tahun 2010-2016. Hipotesis 3: Pengaruh Jumlah Mesin EDC Uang Elektronik Terhadap Perputaran Uang. Variabel Mesin EDC (Jumlah Mesin EDC Uang Elektronik) memiliki nilai probabilitas statistik t sebesar $0.0372<0.05$ yang berarti menerima $\mathrm{H}_{0}$ sehingga dapat dikatakan bahwa Jumlah Mesin EDC Uang Elektronik mempunyai pengaruh signifikan terhadap Perputaran Uang di Indonesia tahun 2010-2016.

Berdasarkan tabel 3. Maka diperoleh model persamaan regresi sebagai berikut:

LPU $=3.413196-0.121435$ LJUEB - 0.025286 LVTUE - 2.670000 MESIN_EDC $+\varepsilon$.

Persamaan regresi berganda di atas dapat dibaca sebagai berikut:

Nilai konstanta sebesar 3.413196, artinya apabila nilai variabel - variabel independen sebesar 0 , maka Nilai Perputaran Uang sebesar 3.413196. Nilai Jumlah Uang Elektronik Beredar sebesar 0.121435 artinya setiap peningkatan Jumlah Uang Elektronik Beredar sebanyak 1 unit akan menaikkan Perputaran Uang sebesar 3.291761 perputaran dengan asumsi variabel independen lainnya tetap. Nilai Volume Transaksi Uang Elektronik tidak signifikan pada alphasebesar 5\%.Nilai Jumlah Mesin EDC Uang Elektronik sebesar 2.670000 artinya setiap peningkatan Jumlah Mesin EDC Uang Elektronik sebanyak 1 unit akan menaikkan Perputaran Uang sebesar 0.743196 perputaran dengan asumsi variabel independen lainnya tetap.

Uji statistik F menunjukkan apakah semua variabel independen dalam model mempunyai pengaruh secara bersama-sama terhadap variabel dependennya. Untuk melakukan uji F dengan cara QuickLook, yaitu : melihat nilai Probability dan derajat kepercayaan yang ditentukan dalam penelitian atau melihat nilai Ftabel dengan F hitungnya. Jika nilai Probability< derajat kepercayaan yang ditentukan dan jika nilai $F$ hitung lebih tinggi dari $\mathrm{F}$ tabel maka suatu variabel independen secara bersama-sama mempengaruhi variabel dependennya. Hasil uji F disajikan pada tabel 4 berikut: 
Tabel 4.Hasil Uji Statistik F (Simultan)

\begin{tabular}{|c|c|}
\hline F-statistic & 329.9978 \\
\hline Prob. (F-statistic) & 0.000000 \\
\hline
\end{tabular}

Sumber: diolahdengan EVIEWS

Tabel 4 diatas menunjukkan bahwa nilai Probability sebesar 0.000000 yang dimana $0.000000<0.05$ yang berarti bahwa Jumlah Uang Elektronik Beredar, Volume Transaksi Uang Elektronik dan Jumlah Mesin EDC Uang Elektronik berpengaruh signifikan secara simultan terhadap Perputaran Uang di Indonesia.Hasil penelitian ini, sejalan dengan hasil penelitian yang dilakukan oleh Siwinastiti, (2014) bahwa penggunaan uang elektronik memiliki pengaruh positif dan signifikan terhadap permintaan uang kartal di Indonesia dalam jangka pendek maupun jangka panjang, yang berarti meningkatnya penggunaan uang elektronik akan mengubah persepsi masyarakat bahwa uang elektronik lebih mudah, simpel, bermanfaat serta aman dibanding uang kartal.

\section{KESIMPULAN}

Kesimpulan dari penelitian ini adalah: (1) jumlah uang elektronik beredar mempunyai pengaruh yang signifikan dan positif terhadap perputaran uang di Indonesia; (2) volume transaksi uang elektronik tidak mempunyai pengaruh yang signifikan terhadap perputaran uang di Indonesia;dan (3) jumlah mesin EDC uang elektronik mempunyai pengaruh yang signifikan dan positif terhadap perputaran uang di Indonesia.Hasil penelitian ini memberikan manfaat bagi Pemerintah, Perbankan dan Institusi perekonomian lainnya untukmemprediksiperputaranuangmelaluijumlah uang elektronik yang beredar, volume transaksi, jumlah mesin EDC terhadap perputaran uang di Indonesia.

Implikasi dan keterbatasan studi

Langkah langkah yang perlu dilakukan dalam percepatan pertumbuhan uang elektronik di Indonesia, antara lain dengan menambah jumlah mesin EDC yang memerikan pengaruh signifikan pada penggunaan uang elektronik.Penelitian ini masih memiliki keterbatasan antara lain: pertama, penelitianinihanya menggunakantiga variabelprediktor dan satuvariabel kriteria yang tentunya masih belum bisa menjelaskan secara komprehensif, maka peneliti selanjutnya dapat menggunakan variabel predictor lain yang masihrelevan dengan tema penelitian. Selanjutnya, jumlah observasi yang terbatas, maka peniliti selanjutnya dapat menambah jumlah observasi.

\section{REFERENSI}

Alghifari. (2013). Analisis Regresi: Teori, Kasus, dan Solusi. Yogyakarta: BPFE-Yogyakarta.

Ariefianto, MD. (2012). Ekonometrika: Esensi dan Aplikasi dengan Menggunakan Eviews.Jakarta: Erlangga.

Cohen, B. J. (2015). A concluding note.ContextoInternacional, 37(3), 1069-1080.

Dou, X. (2018). The determinants of money demand in China. Cogent Economics \& Finance, 6(1), 1564422.

Gujarati, Damodar. (2007). Dasar-dasar Ekonometrika: Jilid 1. Jakarta: Erlangga

Junadi, S. (2015).A model of factors influencing consumer's intention to use e-payment system in Indonesia.Procedia Computer Science, 59, 214-220.

Kartika, VT \& Nugroho, AB. (2015). Analysis On Electronic Money Transactions On Velocity Of Money In Asean-5 Countries. Journal Of Business And Management. Vol. 4, No.9, p. 1008-1020, 2015.https:/ / journal.sbm.itb.ac.id > article > download

Lu, Y., \& Su, Z. (2017, October).The Development Trend of Electronic Money and Its Influence on Currency Liquidity.In 2nd International Symposium on Business Corporation and Development in South-East and South Asia under B\&R Initiative (ISBCD 2017) Atlantis Press. 
AKURASI, 1(2), 79 - 88

Fauzukhaq, M.F., Prasetia, L.D., \& Akbar, A. Perputaran Uang di Indonesia....

Mishkin, Frederic S. (2009). Ekonomi Uang, Perbankan, dan Pasar Keuangan Edisi 8. Jakarta: Salemba Empat.

Pohan, Aulia. (2011). Sistem Pembayaran: Strategi dan Implementasi di Indonesia. Jakarta: PT. RajaGrafindo Persada.

Ramadani, Laila (2016, March 1).Pengaruh Penggunaan Kartu Debit Dan Uang Elektronik (E-Money) Terhadap Pengeluaran Konsumsi Mahasiswa. Jurnal Ekonomi dan Studi Pembangunan JESP-Vol. 8, No, 1.http:// journal.um.ac.id/ index.php/ jesp/ article/ view/ 5266

Rosadi, Dedi. (2012). Ekonometrika dan Analisis Runtun Waktu Terapan dengan Eviews: Aplikasi untuk Bidang Ekonomi, Bisnis, dan Keuangan. Yogyakarta: ANDI.

Siwinastiti, Lutfida. (2014) Analisis Pengaruh Penggunaan Alat Pembayaran Menggunakan Kartu (APMK) Dan Uang Elektronik (E-Money) Terhadap Permintaan Uang Kartal Di Indonesia. (2008:01-2013:12). http:/ / digilib.unila.ac.id/ 4516/

Wulandari, D., Soseco, T., \&Narmaditya, B. S. (2016).Analysis of the use of electronic money in efforts to support the less cash society.International Finance and Banking, 3(1), 1-10.

Yuliadi, Imamudin. (2008). Ekonomi Moneter. Jakarta: PT. INDEKS.

\section{PROFIL PENULIS}

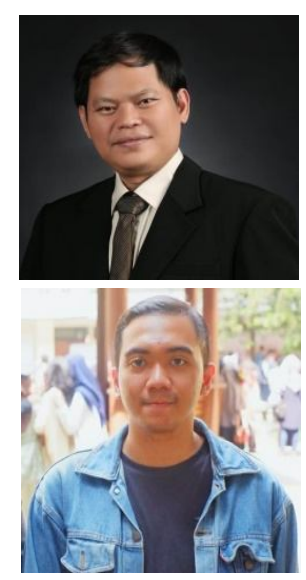

Muhammad Fadlillah Fauzukhaq. Dosen Jurusan Perbankan Syariah, Fakultas Ekonomi dan Bisnis, UIN Syarif Hidayatullah Jakarta, dan Konsultan dibidang Keuangan dan Perbankan, Penulis tertarik melakukan penelitian dibidang Keuangan dan Perbankan. Email: fadlillah.fauzukhaq@uinjkt.ac.id

Luthfan Darma Prasetia. Karyawan swasta di Blibli.com. Alumni Fakultas Ekonomi dan Bisnis UIN Syarif Hidayatullah Jakarta Jurusan Ekonomi Pembangunan. Penulis tertarik melakukan penelitian di bidang Uang Elektronik dan Pembangunan. Email: luthfan.dprasetia@gmail.com

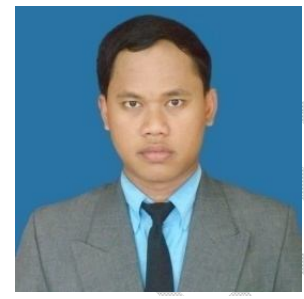

Akhmad Akbar, Dosen jurusan Manajemen Fakultas Ekonomi Universitas Pamulang Tangerang Selatan Banten. Mengampu matakuliah manajemen keuangan 2, Sistem informasi manajemen, koperasi dan UMKM. Penulis tertarik melakukan penelitian manajemen keuangan. Email: akbarakhmad@gmail.com 
AKURASI: JurnalRisetAkuntansidanKeuangan

Vol 1, No. 2, December 2019

Published by LPMP Imperium

AKURASI: Jurnal Riset Akuntansi dan Keuangan

Akurasi: Jurnal Riset Akuntansi dan Keuangan, Vol 1, No.2, Desember 2019, pp. 79-88 eISSN: 2685-2888

Journal homepage: https:// ejournal.imperiuminstitute.org/index.php/AKURASI

Record by

Hendryadi (editor)

STEI Indonesia, Jakarta. Scopus ID: 57211510060 